\title{
Achiral Mannich-Base Curcumin Analogs Induce Unfolded Protein Response and Mitochondrial Membrane Depolarization in PANC-1 Cells
}

\author{
Gábor J. Szebeni ${ }^{1,2}$ (D), Árpád Balázs ${ }^{1}$, Ildikó Madarász ${ }^{1}$, Gábor Pócz ${ }^{1}$, Ferhan Ayaydin ${ }^{3}$, \\ Iván Kanizsai ${ }^{1}$, Roberta Fajka-Boja ${ }^{4}$, Róbert Alföldi ${ }^{1}$, László Hackler Jr. ${ }^{1}$ and \\ László G. Puskás 1,2,* \\ 1 Avidin Ltd., Alsó kikötő sor 11/D, H-6726 Szeged, Hungary; g.szebeni@avidinbiotech.com (G.J.S.); \\ a.balazs@avicorbiotech.com (Á.B.); i.madarasz@avicorbiotech.com (I.M.); pocz.gabor@hotmail.com (G.P.); \\ i.kanizsai@avidinbiotech.com (I.K.); r.alfoldi@avidinbiotech.con (R.A.); hackler@avidinbiotech.com (L.H.) \\ 2 Laboratory of Functional Genomics, Institute of Genetics, Biological Research Centre, \\ Hungarian Academy of Sciences, Temesvári krt. 62, H-6726 Szeged, Hungary \\ 3 Cellular Imaging Laboratory, Institute of Plant Biology, Biological Research Centre, \\ Hungarian Academy of Sciences, Temesvári krt. 62, H-6726 Szeged, Hungary; ayaydin.ferhan@brc.mta.hu \\ 4 Artificial Chromosome and Stem Cell Research Laboratory, Institute of Genetics, Biological Research Centre, \\ Hungarian Academy of Sciences, Temesvári krt. 62, H-6726 Szeged, Hungary; fajka_boja.roberta@brc.mta.hu \\ * Correspondence: laszlo@avidinbiotech.com; Tel.: +36-62-202-107; Fax: +36-62-202-108
}

Received: 26 September 2017; Accepted: 3 October 2017; Published: 7 October 2017

\begin{abstract}
Achiral Mannich-type curcumin analogs have been synthetized and assayed for their cytotoxic activity. The anti-proliferative and cytotoxic activity of curcuminoids has been tested on human non-small-cell lung carcinoma (A549), hepatocellular carcinoma (HepG2) and pancreatic cancer cell line (PANC-1). Based on the highest anti-proliferative activity nine drug candidates were further tested and proved to cause phosphatidylserine exposure as an early sign of apoptosis. Curcumin analogs with the highest apoptotic activity were selected for mechanistic studies in the most sensitive PANC-1 cells. Cytotoxic activity was accompanied by cytostatic effect since curcumin and analogs treatment led to $\mathrm{G}_{0} / \mathrm{G}_{1}$ cell cycle arrest. Moreover, cytotoxic effect could be also detected via the accumulation of curcuminoids in the endoplasmic reticulum (ER) and the up-regulation of ER stress-related unfolded protein response (UPR) genes: HSPA5, ATF4, $X B P 1$, and DDIT3. The activated UPR induced mitochondrial membrane depolarization, caspase- 3 activation and subsequent DNA breakdown in PANC-1 cells. Achiral curcumin analogs, C509, C521 and C524 possessed superior, 40-times more potent cytotoxic activity compared to natural dihydroxy-dimetoxycurcumin in PANC-1 cells.
\end{abstract}

Keywords: curcumin; endoplasmic reticulum stress; unfolded protein response; mitochondrial depolarization; caspase-3; apoptosis

\section{Introduction}

Turmeric spice obtained from the rhizomes of Curcuma longa has been used for centuries in traditional Chinese medicine and in Ayurveda in India based on its assumed anti-inflammatory, anti-microbial, and anti-cancer effects [1]. Curcuminoids make up 2-5\% of turmeric powder and consist of dihidroxy-dimetoxycurcumin (curcumin, 77\%), mono-demethoxycurcumin (17\%) and bis-demethoxycurcumin (3\%) [2]. Due to the empirical beneficial health effect of turmeric the consumption of curcumin as a dietary supplement increased worldwide. By today, curcumin has been designated "Generally Recognized as Safe (GRAS)" by the Food and Drug Administration of 
the United States [3]. The widespread consumption of turmeric and curcumin and its potential as a pharmaceutical laid down the basis for the need of proper scientific studies to reveal the effects of curcumin on human health as well as the design and synthesis of curcumin analogs which can be potentially introduced to the clinic. Our aim was to increase the cytotoxicity of Mannich-type curcumin analogs and reveal their mechanism of action in a cellular system.

Tumorigenesis is a multistep process in which curcumin has been implicated to suppress the growth of tumor cells by reducing their proliferation and survival as well as to induce tumor cell death $[2,4,5]$. It has been published that curcumin inhibited the proliferation and induced the apoptosis of non-small-cell lung carcinoma cells (A549 cell line) by the up-regulation of microRNA-192-5p and suppression of the PI3K3/Akt signaling pathway [6]. In another study apoptosis of A549 cells induced by curcumin relied on oxidative stress and Mitogen-activated protein kinase (MAPK) pathway [7]. Curcumin attenuate not only tumor cell viability but also the metastatic ability of A549 cells by blocking the adiponectin receptor 1 [8] and glucose transporter 1 (GLUT1) [9]. Therefore, we tested our novel curcumin analogs on the non-small cell lung cancer (NSCLC) cell line, A549.

Curcumin caused apoptosis of human hepatocellular carcinoma HepG2 cells as well, via disruption of mitochondrial membrane potential [10] and counteracted fatty acid synthase [11]. In our study, we tested our analogs on both A549 cells as well as on the hepatocellular carcinoma (HCC) cell line HepG2.

Finally, we focused on PANC-1 cells, because among solid tumors, pancreatic malignancy has the highest mortality rate with the overall 5-year survival being less than $6 \%$ [12]. The possible application of curcumin in pancreatic cancer has been reported earlier where the authors showed that PANC-1 cells were sensitive to curcumin treatment via reduction of the inhibitors of apoptosis [13] and through the induction of forkhead box O1 [14].

Here, we present achiral Mannich-type curcumin analogs with potential cytotoxic activity on human NSCLC, hepatocellular carcinoma, and pancreatic cancer cell lines.

\section{Results and Discussion}

\subsection{Achiral Curcumin Analogs Impaired Tumor Cell Viability}

Recently, we have reported the potent cytotoxic activity of racemic Mannich-type curcumin analogs [15-17]. Here, we report the cytotoxic activity of the achiral curcumin analog library (C500 series) (Figure 1 and Figure S1).

A<smiles>COc1cc(/C=C/C(=O)CC(=O)/C=C/c2ccc(O)c(OC)c2)ccc1O</smiles>

B<smiles>[R][R]c1ccc(/C=C/C(=O)C(CNC([R])=O)C(=O)/C=C/c2ccc([R])cc2)cc1</smiles>

Figure 1. Curcumin and the general structure of achiral Mannich-type curcumin analogs. $R^{1}, R^{2}=F$, $\mathrm{OH}, \mathrm{OMe}, \mathrm{COOH}, \mathrm{R}^{3}$ is substituted by aryl or alky groups (each of the substitutes are specified in Figure S1.). 
The substitution pattern was carefully chosen based on the already established structure-activity relationship (SAR) results [17], with the ultimate aim to design a simpler and achiral library of curcuminoids with an improved pharmacokinetic profile. All intermediates and compounds were synthesized based on the previously established method $[17,18]$. As a pre-screening we tested the anti-proliferative effect of the first analog, C501 by measuring the confluency by live cell analyzer of C501 treated A549 cells (Figure S2). Since the anti-proliferative activity of C501 reached its maximum effect at $3.125 \mu \mathrm{M}$, we used lower concentrations of the members of C500 series $(0.16-5 \mu \mathrm{M})$ in the subsequent experiments. We defined the dose-response curves of the 23 members of C500 series by the significantly more sensitive resazurin assay on A549, HepG2, and PANC-1 cells (Figure S3). The half maximal inhibitory concentration $\left(\mathrm{IC}_{50}\right)$ values are presented in Table 1 . The $\mathrm{IC}_{50}$ value of curcumin was above the pharmacologically favorable range $27.11 \mu \mathrm{M}, 14.53 \mu \mathrm{M}$, and $30.57 \mu \mathrm{M}$ in A549, HepG2, and PANC-1 cells, respectively. Six molecules were completely inactive at the applied concentrations (C514, C520, C525, C526, C529, and C530) and were not tested further. This was in full accordance with previously established SAR results [17,18], that the presence of functionalities such as carboxylic acid, dihydroxyphenyl, or para-hydroxy substituents resulted in the complete loss of cytotoxic activity. Compounds which possessed low anti-proliferative activity ( $\mathrm{IC}_{50}>5 \mu \mathrm{M}$ ) were also excluded from further testing (C502, C510, C513, C516, C517, C519, C532, and C533). The current project focused on curcumin analogs with potent cytotoxic activity on three different cell lines: A549, HepG2, and PANC-1. Nine of the 23 novel curcumin analogs (C501, C503, C504, C505, C509, C515, C518, C521, and C524) hampered the viability of all three tested cell lines when used below $5 \mu \mathrm{M}$.

Table 1. $\mathrm{IC}_{50}$ values $(\mu \mathrm{M})$ of curcumin (Curc.) and curcumin analogs determined by resazurin assay.

\begin{tabular}{|c|c|c|c|}
\hline Compound & A549 & HepG2 & PANC-1 \\
\hline Curc. & 27.11 & 14.53 & 30.57 \\
\hline C501 \# & 1.26 & 0.66 & 1.44 \\
\hline C502 & 2.39 & $>5$ & 2.20 \\
\hline C503 \# & 1.70 & 2.55 & 1.66 \\
\hline C504 \# & 1.58 & 1.24 & 1.40 \\
\hline $\mathrm{C} 505^{\#}$ & 1.29 & 1.48 & 1.43 \\
\hline C509 \# & 2.27 & 2.98 & 1.01 \\
\hline C510 & $>5$ & 1.07 & $>5$ \\
\hline C513 & $>5$ & 3.11 & $>5$ \\
\hline C514 & inactive & inactive & inactive \\
\hline C515 \# & 2.73 & 1.31 & 1.46 \\
\hline C516 & $>5$ & 4.19 & $>5$ \\
\hline C517 & $>5$ & $>5$ & 2.45 \\
\hline $\mathrm{C} 518^{\#}$ & 2.42 & 4.77 & 1.25 \\
\hline C519 & $>5$ & $>5$ & $>5$ \\
\hline C520 & inactive & inactive & inactive \\
\hline C521 \# & 1.88 & 1.36 & 1.18 \\
\hline $\mathrm{C} 524^{\#}$ & 1.70 & 1.69 & 1.14 \\
\hline C525 & inactive & inactive & inactive \\
\hline C526 & inactive & inactive & inactive \\
\hline C529 & inactive & inactive & inactive \\
\hline C530 & inactive & inactive & inactive \\
\hline C532 & $>5$ & $>5$ & 1.58 \\
\hline C533 & $>5$ & 4.81 & $>5$ \\
\hline
\end{tabular}

Cells were treated with curcumin $(1.56,3.125,6.25,12.5,25$, and $50 \mu \mathrm{M})$ and curcumin analogs $(0.16,0.3125,0.625$, $1.25,2.5$, and $5 \mu \mathrm{M})$ in duplicates for $72 \mathrm{~h}$. Viability was examined by resazurin assay as described in Section 3.2. Materials and Methods. Hashmark $(\#)$ labeled curcumin analogs were selected for further investigation.

\subsection{Curcumin Analogs Induced Phosphatidylserine Exposure of A549, HepG2 and PANC-1 Cells}

In order to clarify whether the viability of A549, HepG2, and PANC-1 cells was hampered by apoptosis or necrosis, we carried out annexin V-propidium iodide (PI) staining on the cells treated by 
the nine selected candidates. Curcumin and its analogs showed dose dependent phosphatidylserine exposure that suggests potent apoptotic activity $\left(\mathrm{AnnV}^{+} / \mathrm{PI}\right.$ early apoptosis and $\mathrm{AnnV}^{+} / \mathrm{PI}^{+}$late apoptosis) in A549 (Figure 2A), HepG2 (Figure 2B), and PANC-1 cells (Figure 2C) without the appearance of a massive, only PI positive necrotic population (Figure S4).
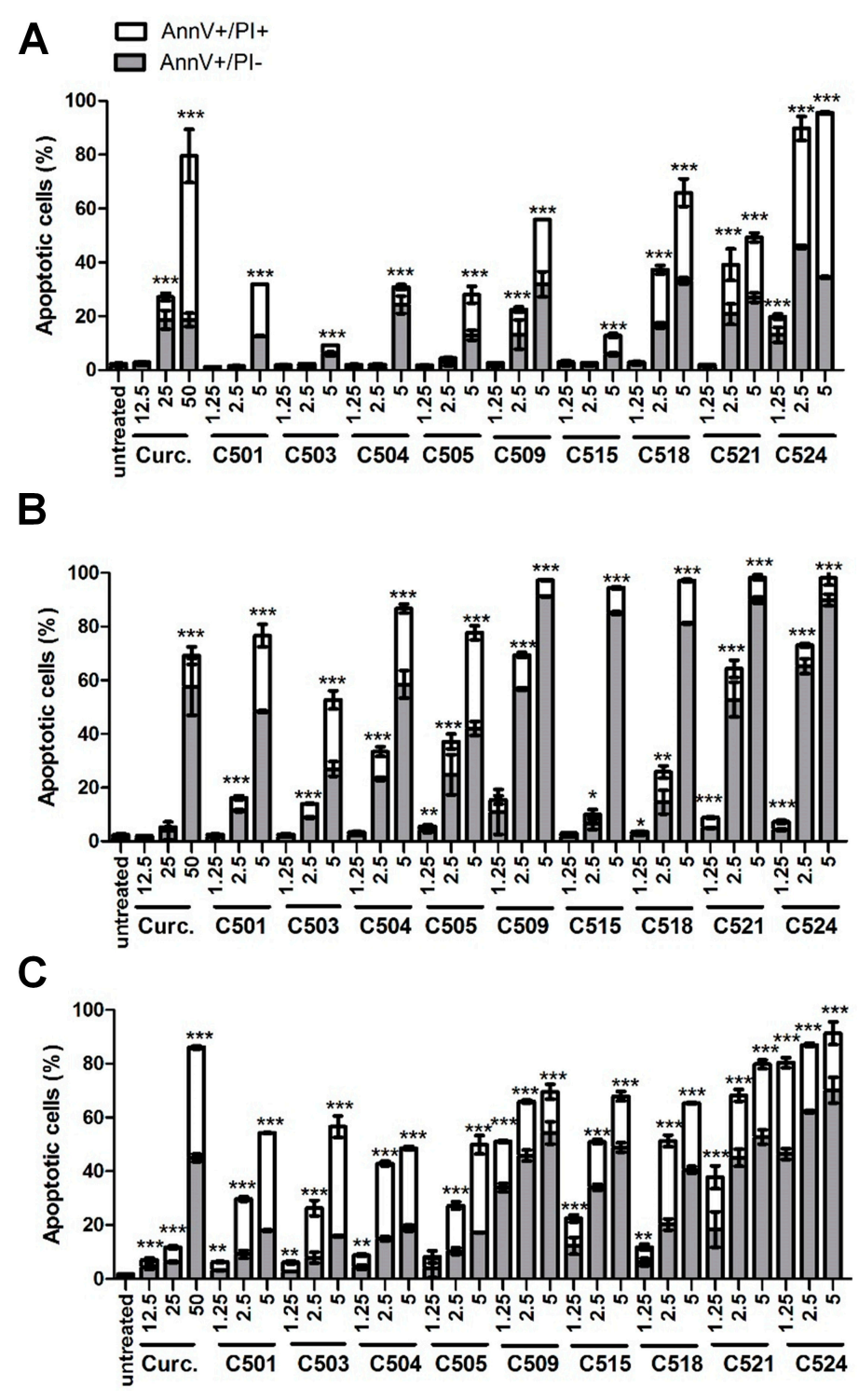

Figure 2. Curcumin and analogs induced phosphatidylserine exposure on tumor cells. A549 (A), HepG2 (B), and PANC-1 (C) cells were incubated with curcumin (Curc.) and curcumin analogs with the indicated concentrations $(\mu \mathrm{M})$ as described in Section 3.3.1. Materials and Methods. The results are shown as arithmetic mean values of the summary of early $\left(\mathrm{AnnV}^{+} / \mathrm{PI}^{-}\right.$, gray column) and late apoptosis (AnnV $\mathrm{PI}^{+}$, white column) of two samples $\pm \mathrm{SD},{ }^{*} p<0.05,{ }^{* *} p<0.01,{ }^{* * *} p<0.001$.

In order to identify the most active analogs, we summarized the percentage of total apoptotic cell populations at the lowest applied concentration for each analog in Table 2. Three compounds stood out with appreciable activity, C509, C521, and C524, therefore only these were included in further experiments. All three molecules share the common C-4 chloroacetamidomethyl and either the meta-hydroxy or methoxy substituents on their side-chains. An analog with moderate activity, was also included (C501) in our analyses. Since PANC-1 cells were the most sensitive in our study, additionally the 5 -year overall survival has been reported to be the lowest for pancreatic cancer (less than $6 \%$ ) 
among other solid malignancies [12], we used PANC-1 cells for subsequent mechanistic studies to reveal how novel curcumin analogs counteract cancer cell viability.

Table 2. The percentage of apoptotic cells at the lowest applied concentration of $12.5 \mu \mathrm{M}$ curcumin and $1.25 \mu \mathrm{M}$ curcumin analogs.

\begin{tabular}{|c|c|c|c|}
\hline Compound & A549 & HepG2 & PANC-1 \\
\hline None & $2.4 \pm 0.44$ & $2.7 \pm 0.37$ & $1.8 \pm 0.02$ \\
\hline Curcumin & $3.0 \pm 0.30$ & $2.0 \pm 0.14$ & $7.0 \pm 0.02$ \\
\hline C501 $\#$ & $1.3 \pm 0.06$ & $2.6 \pm 0.55$ & $6.3 \pm 0.42$ \\
\hline C503 & $\mathbf{1 . 9} \pm 0.83$ & $2.6 \pm 0.33$ & $6.1 \pm 0.54$ \\
\hline C504 & $2.0 \pm 0.16$ & $3.4 \pm 0.28$ & $8.8 \pm 1.36$ \\
\hline C505 & $1.8 \pm 0.11$ & $5.6 \pm 0.31$ & $8.2 \pm 5.83$ \\
\hline C509" \# & $2.7 \pm 0.25$ & $15.4 \pm 9.92$ & $\mathbf{5 1 . 0} \pm 1.17$ \\
\hline C515 & $3.0 \pm 0.77$ & $3.1 \pm 0.11$ & $22.5 \pm 4.43$ \\
\hline C518 & $3.0 \pm 0.01$ & $3.6 \pm 0.33$ & $\mathbf{1 1 . 8} \pm 2.49$ \\
\hline C521 \# & $2.5 \pm 0.5$ & $8.9 \pm 0.13$ & $37.8 \pm 10.86$ \\
\hline C524 ${ }^{\#}$ & $19.8 \pm 3.81$ & $7.3 \pm 0.37$ & $80.4 \pm 0.13$ \\
\hline
\end{tabular}

Phosphatidylserine exposure was examined as described in Section 3.3.1. Materials and Methods. Analogs labeled with a hashmark $(\#)$ were selected for further investigation, ( \pm refers to standard deviation)

\subsection{Curcumin Analogs Caused $G_{0} / G_{1}$ Cell-Cycle Arrest of PANC-1 Cells}

In addition to cytotoxicity, we also investigated the cytostatic effect of our curcumin analogs on PANC-1 cells. Curcumin $(25 \mu \mathrm{M})$, and C509, C521, and C524 (both $1.25 \mu \mathrm{M})$ significantly increased $\mathrm{G}_{0} / \mathrm{G}_{1}$ population of PANC-1 cells (up to $80 \%$ ) compared to the untreated control cells ( $40 \%$ ) (Figure 3 and Figure S5).

According to several reports it is unequivocal that curcumin can dysregulate the cell cycle. It has been reported that natural curcumin caused $G_{2} / M$ mitotic catastrophy, in relation to the $G_{2} / M$ phase in head and neck squamous cell carcinoma or in bovine aortic endothelial cells after $24 \mathrm{~h}$ incubation $[19,20]$, it was also shown that curcumin caused not only $G_{1} / S$ but also $G_{0} / G_{1}$ cell cycle arrest in human prostate cancer cells [21,22]. The differences in cell cycle dysregulation may be cell type specific or may depend on the different experimental conditions, incubation time period, the concentration and formulation of curcumin.

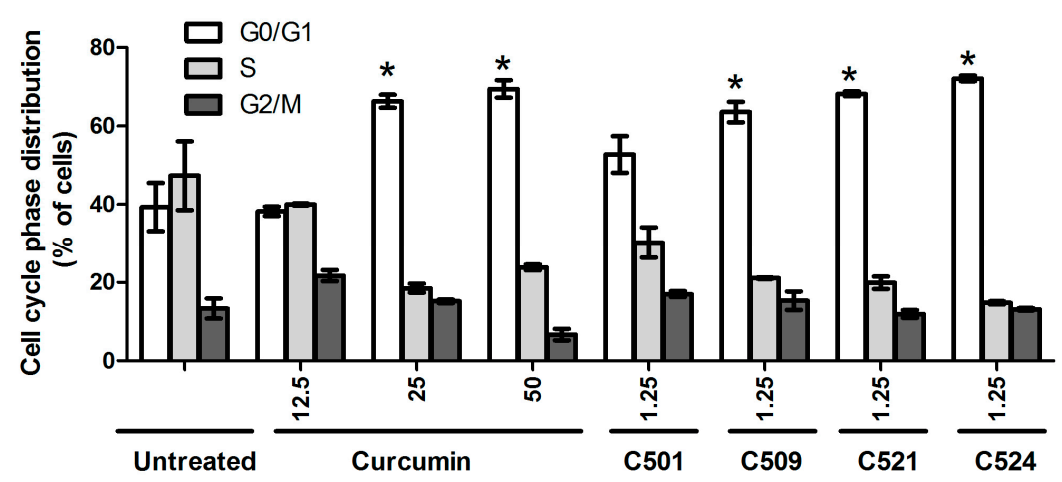

Figure 3. Curcumin and analogs caused $G_{0} / G_{1}$ arrest of PANC-1 cells. Cells were treated with curcumin and curcumin analogs with the indicated concentrations $(\mu M)$ in the figure and $G_{0} / G_{1}, S$, $\mathrm{G}_{2} / \mathrm{M}$ cell cycle phase distributions were analyzed by flow cytometry as described in Section 3.3.2. Materials and Methods. The results are shown as arithmetic mean values of two samples $\pm \mathrm{SD},{ }^{*} p<0.05$. 


\subsection{Curcumin Analogs Induced ER (Endoplasmic Reticulum) Stress and Mitochondrial Membrane Depolarization}

Among others, we have previously shown that perturbing the homeostasis of the ER could reduce cellular viability [23]. It was recently published that natural curcumin caused ER stress mediated apoptosis in cervical cancer cells [24] and in A549 cells [7]. In order to clarify whether the apoptotic effect of curcumin analogs in PANC-1 cells relied on the ER stress related mitochondrial apoptotic pathway, we followed the accumulation of the tested agents. Since curcumin possesses inherent fluorescence [25] and our analogs retained this property, we tested the subcellular localization of curcumin and our analogs in PANC-1 cells by fluorescence confocal microscopy. Similarly to curcumin, our analogs localized in the ER which was further verified by ER tracker co-localization (Figure 4).
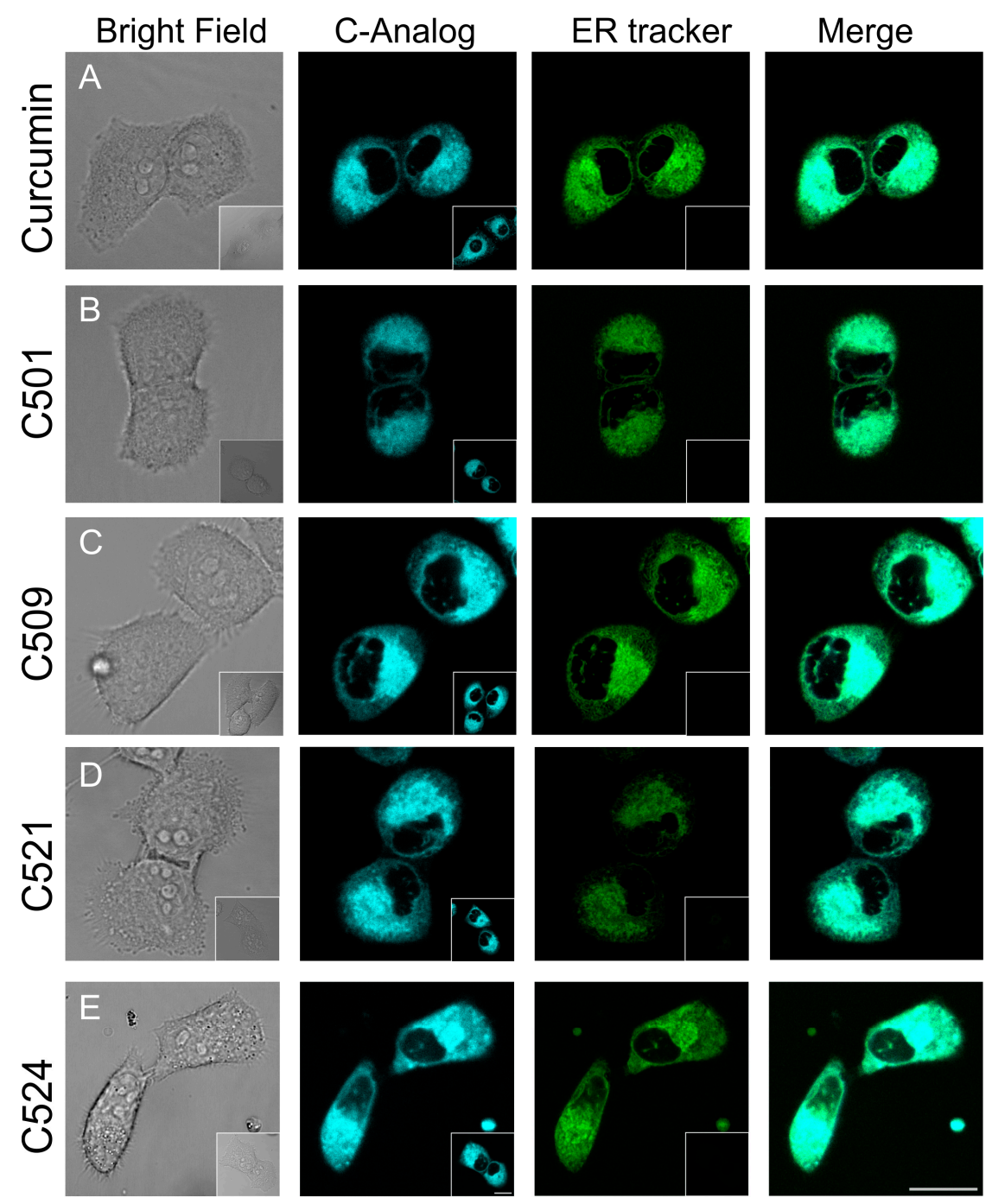

Figure 4. Curcumin and analogs localized in the endoplasmic reticulum of PANC-1 cells. Cells were treated with curcumin and analogs (A-E), $1 \mu \mathrm{M}$ and $5 \mathrm{~min}$. The subcellular localization of curcumin and its analogs was assessed with endoplasmic reticulum (ER) tracker co-localization by laser scanning confocal microscopy. To further minimize channel crosstalk, only curcumin analog labeled samples were also prepared (inset images) and used as reference for image capturing conditions for curcumin-ER tracker dual labelled samples. Representative images are shown. Scale bar at C524 inset image is valid for all insets (controls). Scale bar at the lower right corner of C524 is valid for all ER co-localization images. Both scale bars are $20 \mu \mathrm{m}$. 
The subcellular localization of curcumin analogs in the ER may activate an adaptive response to ER stress known as the unfolded protein response (UPR), which up-regulates ER chaperons, halts translation of secretory proteins, and degrades misfolded proteins. If the ER stress is irreversible the UPR mediates apoptotic cell death to restore the cell homeostasis [26]. ER stress was monitored by the induction of UPR related genes: HSPA5 (Heat Shock Protein Family A (Hsp70) Member 5), ATF4 (Activating Transcription Factor 4), XBP1 (X-Box Binding Protein 1), and DDIT3 (DNA Damage Inducible Transcript 3). HSPA5 is a chaperon, master regulator of the UPR [27], ATF4, and XBP1 are transcriptional activators of UPR genes and chaperons [28], DDIT3 (encoding CHOP) is a transcription factor mediating ER stress related apoptosis [17,26,29].

Curcumin and the tested analogs induced the expression of all tested genes $12 \mathrm{~h}$ after treatment (Figure 5). The up-regulation of HSPA5 was two-fold by $12.5 \mu \mathrm{M}$ curcumin and around 10-fold by $1.25 \mu \mathrm{M} \mathrm{C509,} \mathrm{C521,} \mathrm{and} \mathrm{C524} \mathrm{treatment.} \mathrm{ATF4} \mathrm{and} \mathrm{XBP1} \mathrm{were} \mathrm{around} \mathrm{4-5-fold} \mathrm{up-regulated} \mathrm{upon}$ curcumin and curcumin analog stimulation. The highest increase was detected in case of DDIT3, where a 13-fold increase was detected with curcumin $(25 \mu \mathrm{M})$, while the analogs induced around 30 -fold overexpression at $1.25 \mu \mathrm{M}$, only C501 showed 60-fold change at $5 \mu \mathrm{M}$. DDIT3 overexpression may suggest that in curcumin and curcumin analog treated cells the UPR progressed to a state where homeostasis cannot be restored and the cells are committed to an apoptotic fate [29,30]. The concentration dependent decline of gene expression changes (50 $\mu \mathrm{M}$ curcumin and $5 \mu \mathrm{M}$ C509, C521, and C524) may be due to the advanced apoptotic program.
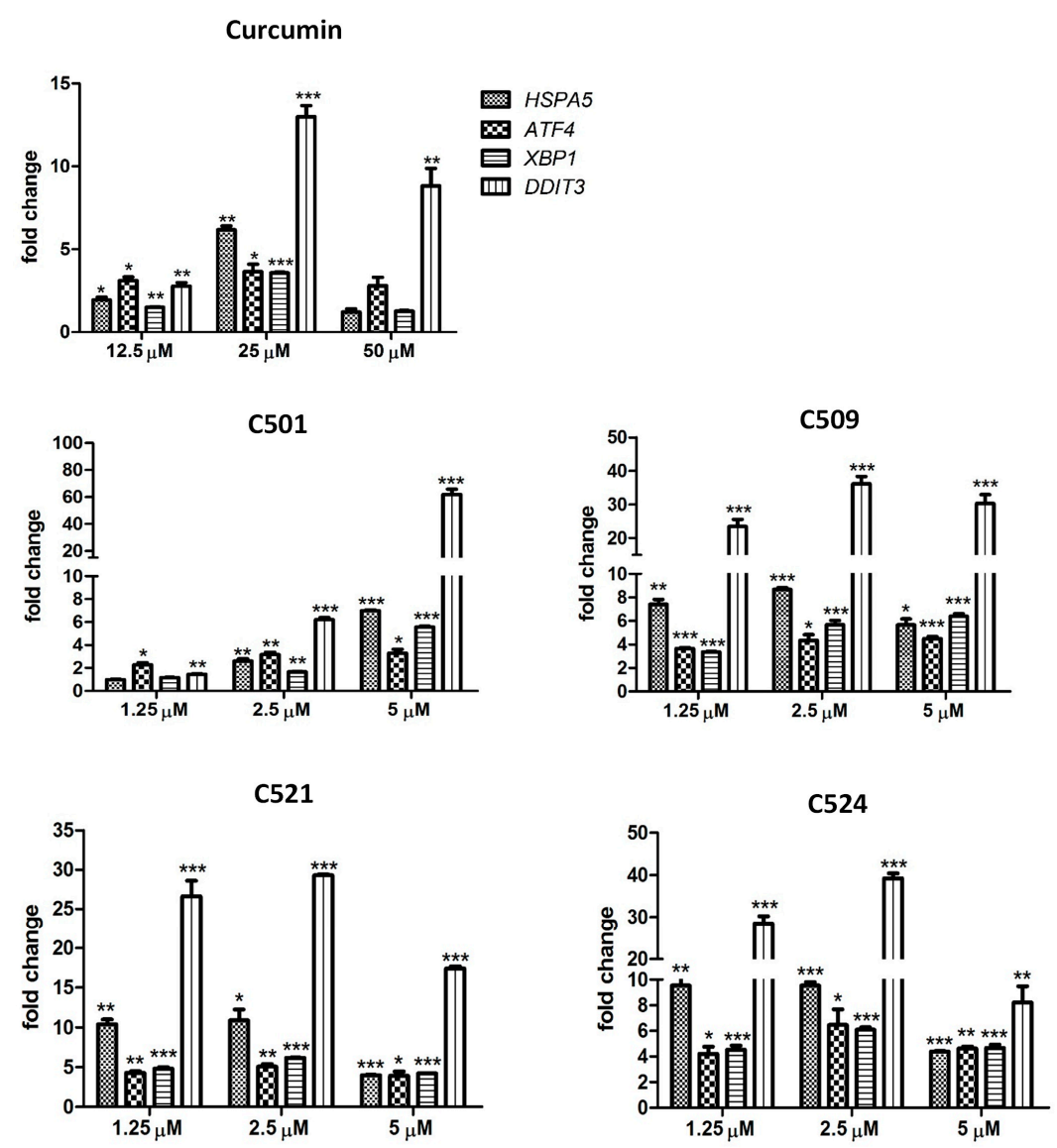

Figure 5. Curcumin analogs induced unfolded protein response during ER stress. Gene expression of unfolded protein response genes: HSPA5, ATF4, XBP1, DDIT3 (arithmetic means of fold changes \pm SD) in PANC-1 cells treated with curcumin and curcumin analogs after $12 \mathrm{~h}$. Gene expression was analyzed by qRT-PCR (quantitative real-time polymerase chain reaction) as described in the Section 3.5. Materials and Methods, ${ }^{*} p<0.05,{ }^{* *} p<0.01,{ }^{* * *} p<0.001$. 
The perturbation of the homeostasis of the ER by curcumin analogs may confound the subcellular oxidative homeostasis affecting mitochondrial membrane potential (MMP) [31]. Therefore, mitochondrial membrane depolarization was examined by JC-1 (5,5',6, $6^{\prime}$-tetrachloro- $1,1^{\prime}, 3,3^{\prime}$ tetraethylbenzimidazolocarbocyanine iodide) staining following curcumin and curcumin analog treatment of PANC-1 cells. Not only curcumin but also our analogs depolarized mitochondria of PANC-1 cells in a concentration dependent manner (Figure 6). The effect of curcumin on MMP was significant at $50 \mu \mathrm{M}$, while C501 analog was effective at $5 \mu \mathrm{M}, \mathrm{C} 509$ at $2.5 \mu \mathrm{M}$, and C521 and C524 at $1.25 \mu \mathrm{M}$.
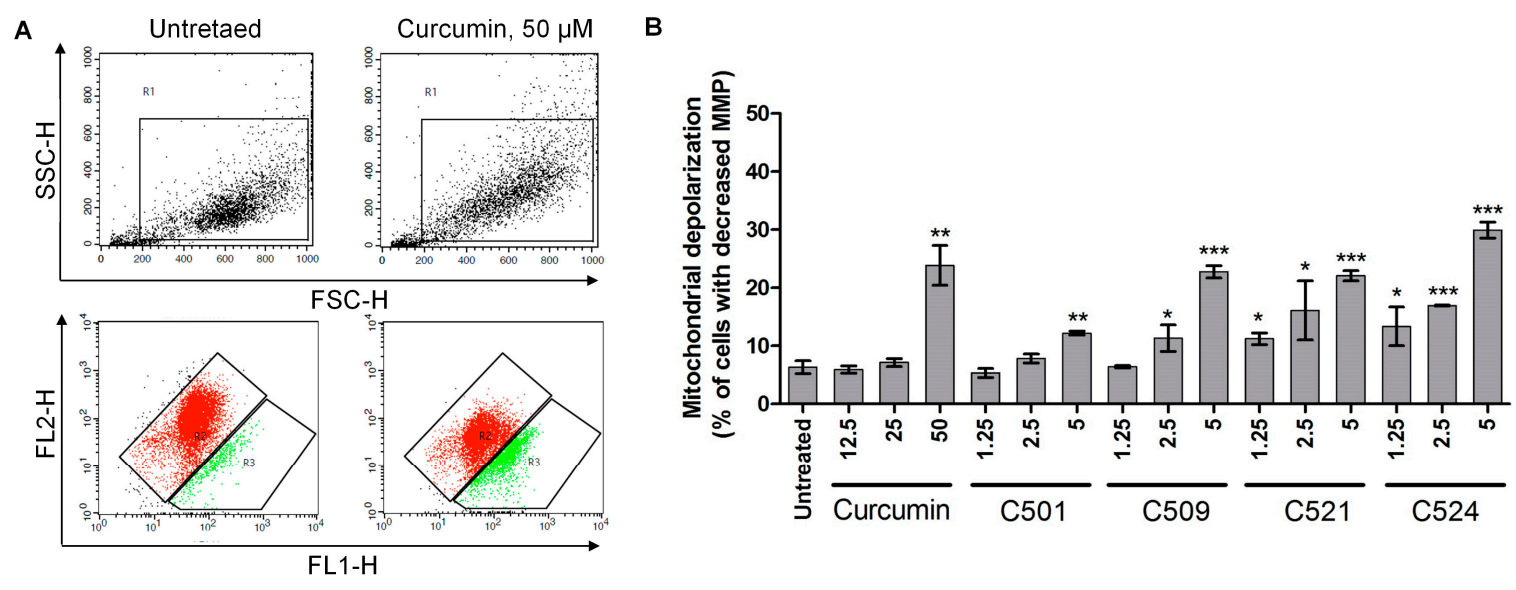

Figure 6. Curcumin and analogs depolarized mitochondria of PANC-1 cells examined by JC-1 staining. (A) Representative SSC-FSC and FL2-FL1 dot plots and (B) arithmetic means of percentages ( \pm SD) of cells with decreased MMP at $24 \mathrm{~h}$ following treatment $(\mu \mathrm{M})$. JC- 1 was analyzed by flow cytometry as described in Section 3.3.4. Materials and Methods, ${ }^{*} p<0.05,{ }^{* *} p<0.01,{ }^{* * *} p<0.001$.

\subsection{Curcumin Analogs Induced Caspase-3 Activation and DNA Fragmentation}

Mitochondrial membrane depolarization may lead to the activation of caspases which renders cells for apoptosis [32]. Effector caspase-3 activation occurred in PANC-1 cells following curcumin and curcumin analog treatment in a concentration dependent manner (Figure 7). Among curcumin analogs C524 showed the highest induction of caspase- 3 at $5 \mu \mathrm{M}$.

Apoptosis executed by the activation of caspases results in the internucleosomal degradation of genomic DNA which can be studied by flow cytometry as a hypodiploid sub- $\mathrm{G}_{1}$ fraction of the cell population [33]. In order to confirm that event we analyzed the percentage of cells with degraded DNA content (Figure 8A). Using PANC-1 cells, our results showed that treatment with curcumin resulted in DNA degradation at $25 \mu \mathrm{M}$, while curcumin analogs exerted a significant effect at $1.25 \mu \mathrm{M}$. Cytotoxicity of the curcumin analogs resulted in DNA breakdown as the final step of apoptosis in a concentration dependent manner (Figure 8B). 
A
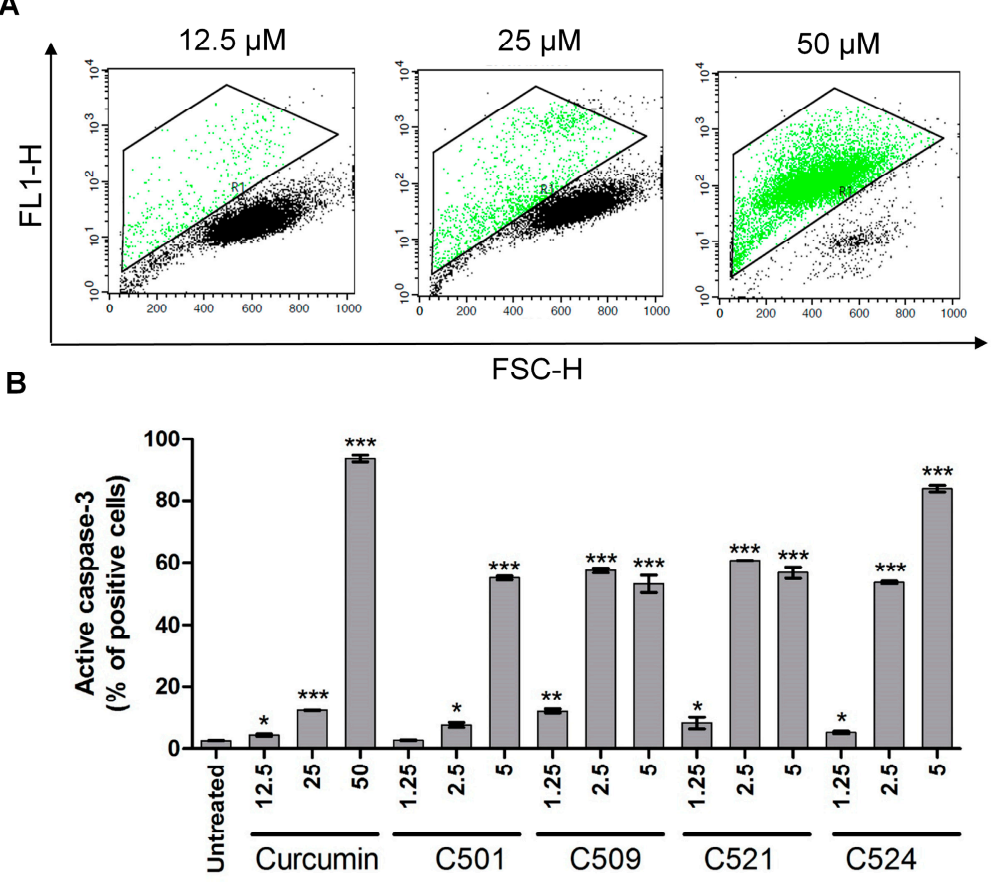

Figure 7. Curcumin and analogs activated caspase-3 in PANC-1 cells. (A) Representative FL1-FSC dot plots and (B) arithmetic means of percentages \pm SD of cells with active caspase- 3 show data of cells treated with curcumin and curcumin analogs with the indicated concentrations $(\mu \mathrm{M})$ on the graph for $72 \mathrm{~h}$. Active caspase- 3 was analyzed by flow cytometry as described in Section 3.3.3. Materials and Methods, ${ }^{*} p<0.05,{ }^{* *} p<0.01,{ }^{* * *} p<0.001$.

A
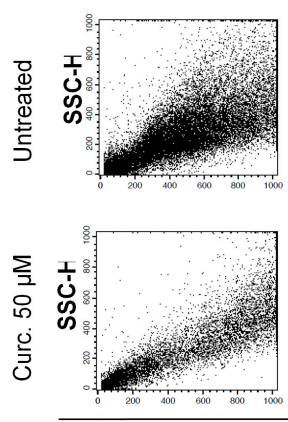
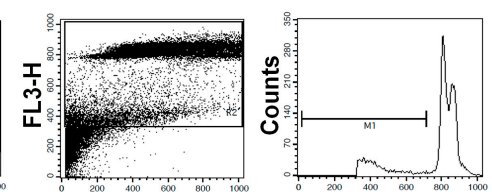

FL3-H
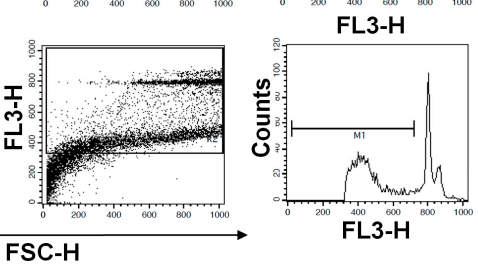

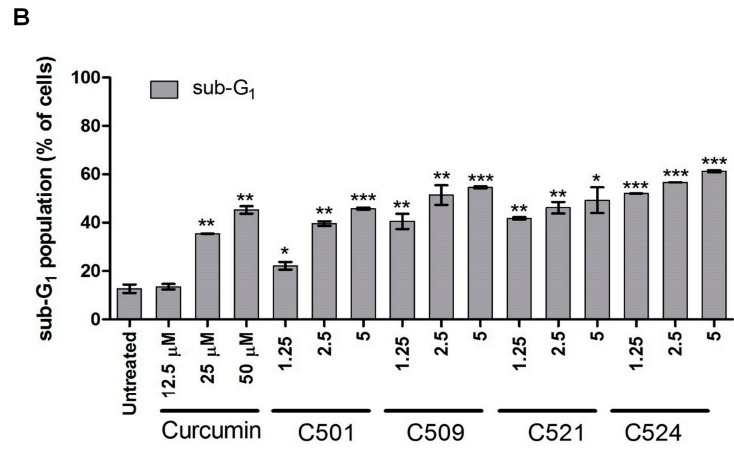

Figure 8. Curcumin analogs caused DNA breakdown of PANC-1 cells. (A) Representative SSC-FSC, FL3-FSC dot plots (gating out debris) and FL3 histograms are presented. (B) The arithmetic mean values of replicates $\pm \mathrm{SD}$ are presented. Cells were treated with curcumin and curcumin analogs with the indicated concentrations $(\mu \mathrm{M})$ in the figure in duplicates for 72. Sub-G1 population was analyzed by flow cytometry as described in Section 3.3.2. Materials and Methods, ${ }^{*} p<0.05,{ }^{* *} p<0.01,{ }^{* * *} p<0.001$.

\section{Materials and Methods}

\subsection{Cell Culturing and Treatments}

Cells were purchased from the American Type Culture Collection (ATCC, Manassas, Virginia, USA). A549, HepG2 cells were maintained in Dulbecco's Modified Eagle Medium/Nutrient Mixture F-12 (DMEM/F12) 10\% fetal calf serum (FCS, Gibco) and PANC-1 cells were maintained in Roswell Park Memorial Institute 1640 medium (RPMI-1640) 10\% FCS, pH of the cell culture media was controlled to be between 7.2-7.4 prior use. Media were supplemented with $2 \mathrm{mM}$ GlutaMAX, and $100 \mathrm{U} / \mathrm{mL}$ 
penicillin, $100 \mu \mathrm{g} / \mathrm{mL}$ streptomycin (Life Technologies, Carlsbad, California, USA). The cell cultures were maintained at $37^{\circ} \mathrm{C}$ in a humidified incubator in an atmosphere of $5 \% \mathrm{CO}_{2}$ (Sanyo, Japan).

Curcumin and curcumin analogs were dissolved in dimethyl sulfoxide (DMSO) at $10 \mathrm{mM}$ concentration. Since DMSO can be toxic for cellular systems, the stock solution was further diluted in serial dilutions in all cases in the appropriate cell culture media. The intermediate dilution of curcumin was $250 \mu \mathrm{M}(40 \times$ dilution), it was serially diluted to $125 \mu \mathrm{M}(80 \times$ dilution $)$ and it was further diluted to $62.5 \mu \mathrm{M}(160 \times$ dilution), then each intermediate dilution was further diluted $5 \times$ when it was added to the cells, so the treatments of curcumin were $50 \mu \mathrm{M}(200 \times), 25 \mu \mathrm{M}(400 \times)$ and $12.5 \mu \mathrm{M}(800 \times)$. The intermediate dilution of curcumin analogs was $25 \mu \mathrm{M}(400 \times)$, it was serially diluted to $12.5 \mu \mathrm{M}$ $(800 \times$ dilution) and it was further diluted to $6.25 \mu \mathrm{M}(1600 \times$ dilution $)$, then each intermediate dilution was further diluted $5 \times$ when it was added to the cells so the treatments of curcumin analogs were $5 \mu \mathrm{M}(2000 \times), 2.5 \mu \mathrm{M}(4000 \times)$, and $1.25 \mu \mathrm{M}(8000 \times)$.

\subsection{Resazurin Viability Assay}

The viability of A549, HepG2, and PANC-1 cells was determined by the fluorescent resazurin assay as described previously [34]. Briefly, cells $\left(6 \times 10^{3}\right)$ were seeded into 96-well plates (Corning Life Sciences, Tewksbury, MA, USA) in media. Cells were cultured overnight before treatment. Viability was determined after a $72 \mathrm{~h}$ incubation in treated and non-treated cells. Resazurin reagent (Sigma-Aldrich) was dissolved in phosphate buffered saline (PBS, pH 7.4) at $0.15 \mathrm{mg} / \mathrm{mL}$ concentration, sterile filtered $\left(0.22 \mu \mathrm{m}\right.$, Merck Millipore) and aliquoted at $-20^{\circ} \mathrm{C}$. Samples were treated in $120 \mu \mathrm{L}$ volume with a final concentration of $25 \mu \mathrm{g} / \mathrm{mL}$ resazurin. After 2 hours incubation at $37^{\circ} \mathrm{C} 5 \% \mathrm{CO}_{2}$, fluorescence (530 nm excitation/580 nm emission) was recorded on a multimode microplate reader (Cytofluor4000, PerSeptive Biosytems, Framingham, MA, USA). Viability was calculated in relation to untreated control cells and blank wells containing media without cells. The presented $\mathrm{IC}_{50}$ values (half maximal inhibitory concentration) were determined based on dose-response curves plotted in GraphPad Prism ${ }^{\circledR} 5$ (La Jolla, CA, USA).

\subsection{Flow Cytometry}

\subsubsection{Detection of Phosphatidylserine Exposure}

Cells $\left(5 \times 10^{4}\right)$ were plated in 24-well tissue culture plates (Corning Life Sciences) and treated in $500 \mu \mathrm{L}$ volume with increasing concentrations of test compounds in duplicates. After $72 \mathrm{~h}$ the supernatants were harvested. Cells were washed with PBS, trypsinized, pooled with the corresponding supernatant and pelleted by centrifugation $(2000 \mathrm{rpm}, 5 \mathrm{~min})$. The pellet was resuspended in annexin $\mathrm{V}$ binding buffer (0.01 M HEPES (4-(2-hydroxyethyl)-1-piperazineethanesulfonic acid), $0.14 \mathrm{M} \mathrm{NaCl}$ and $2.5 \mathrm{mM} \mathrm{CaCl}_{2}$ ). Annexin V-Alexa Fluor ${ }^{\circledR} 488$ (AnnV, Life Technologies, 2.5:100) was added to the cells, which were then kept in the dark at room temperature for $15 \mathrm{~min}$. Propidium iodide (PI, Sigma-Aldrich, St. Louis, MO, USA) was added at a final concentration of $10 \mu \mathrm{g} / \mathrm{mL}$ right before the acquisition of samples. Cells $\left(2 \times 10^{4}\right.$ events) were analyzed on a FACSCalibur flow cytometer using CellQuest software (Becton Dickinson, Franklin Lakes, NJ, USA). The percentage of annexin V-Alexa Fluor ${ }^{\circledR}$ 488 positive (FL1 channel, 530/30 nm filter) and propidium iodide negative (FL3 channel, $670 \mathrm{~nm}$ filter) early apoptotic cells and FL1 positive and FL3 positive late apoptotic cells were determined. The total apoptotic population includes both early and late apoptotic cells. Bar graphs were created by GraphPad Prism ${ }^{\circledR} 5$.

\subsubsection{Cell Cycle and Sub- $G_{1}$ Analysis}

PANC-1 cells $\left(5 \times 10^{4}\right)$ were plated in 24-well tissue culture plates (Corning Life Sciences) in RPMI $10 \%$ FCS and were treated in $500 \mu \mathrm{L}$ media containing test compounds in duplicates. After $72 \mathrm{~h}$ the supernatant was harvested. Cells were washed with PBS, trypsinized, pooled with the corresponding supernatant and centrifuged (2000 rpm, $5 \mathrm{~min}$ ). Pellet was resuspended in DNA 
binding buffer (1× PBS, $0.1 \%$ tri-sodium-citrate, $10 \mu \mathrm{g} / \mathrm{mL}$ PI, $0.1 \%$ Triton X-100, $10 \mu \mathrm{g} / \mathrm{mL}$ RNase A, (Sigma-Aldrich)). After incubation at room temperature for $30 \mathrm{~min} 2 \times 10^{4}$ events were acquired on a FACSCalibur flow cytometer (Becton Dickinson). Sub- $\mathrm{G}_{1}$ apoptotic population was analyzed on FL3 histograms using CellQuest ${ }^{\mathrm{TM}}$ software (Becton Dickinson). We gated out doublets for cell cycle analysis which was based on FL2-A/FL2-W dot plots, using Modfit software (Becton Dickinson). Bar graphs were created by GraphPad Prism ${ }^{\circledR} 5$.

\subsubsection{Immunofluorescence}

PANC-1 cells $\left(1 \times 10^{5}\right)$ were plated in 24-well tissue culture plates (Corning Life Sciences) in RPMI $10 \%$ FCS and were treated in $500 \mu \mathrm{L}$ media containing test compounds. After $72 \mathrm{~h}$ the supernatant was harvested. Cells were washed with PBS, trypsinized, pooled with the corresponding supernatant and centrifuged (2000 rpm, $5 \mathrm{~min}$ ). Pellet was resuspended and fixed in 3.5\% PBS buffered formaldehyde (Molar Chemicals) for $10 \mathrm{~min}$. Cells were washed with FACS-buffer ( $2 \%$ FCS in PBS), centrifuged (2000 rpm, $5 \mathrm{~min})$. Cells were permeabilized in permeabilization buffer ( $1 \% \mathrm{FCS}, 0.1 \%$ saponin (Sigma-Aldrich) in PBS pH 7.4) for 5 min. Cells were washed with FACS buffer (2\% FCS in PBS), centrifuged (2000 rpm, $5 \mathrm{~min}$ ). Rabbit polyclonal anti-cleaved caspase-3 antibody (9661S, Cell Signaling) was added at 1:600 dilution in FACS buffer. After incubation for $1 \mathrm{~h}$ at $4{ }^{\circ} \mathrm{C}$ samples were washed two times with FACS buffer. The secondary antibody, polyclonal goat anti-rabbit IgG conjugated with Alexa Fluor ${ }^{\circledR} 488$ (A11008, Thermo Fisher Scientific, Waltham, MA, USA) was diluted to 1:600 and incubated with the cells for $30 \mathrm{~min}$ at $4{ }^{\circ} \mathrm{C}$. After washing, $300 \mu \mathrm{L}$ FACS buffer was added for acquisition with the FACSCalibur flow cytometer acquiring $2 \times 10^{4}$ events at FL1 channel. Data were analyzed using CellQuest ${ }^{\mathrm{TM}}$ software (Becton Dickinson) gating out debris. In order to calculate the signal to noise ratio, median fluorescence intensity (MFI) was calculated by the following equation: $\mathrm{MFI}=10^{[(\text {Median stained }- \text { Median unstained, untreated)/Chd }]}$, where Chd (the number of channels per decade) equals 256, [35,36]. Bar graphs were created by GraphPad Prism ${ }^{\circledR} 5$.

\subsubsection{Detection of the Loss of Mitochondrial Membrane Potential}

PANC-1 cells $\left(1 \times 10^{5}\right)$ were plated in 24-well tissue culture plates (Corning Life Sciences) in RPMI $10 \%$ FCS and were treated in $500 \mu \mathrm{L}$ media containing test compounds. After $24 \mathrm{~h}$, the supernatants were harvested. Cells were washed with PBS, trypsinized, pooled with the corresponding supernatant and centrifuged (2000 rpm, $5 \mathrm{~min}$ ). Pellet was resuspended and incubated for $15 \mathrm{~min}$ in $5 \mu \mathrm{g} / \mathrm{mL}$ JC-1 (5, 5' '6, $6^{\prime}$-tetrachloro-1,1',3,3'-tetraethylbenzimidazolocarbocyanine iodide, Chemodex) containing media in final volume $300 \mu \mathrm{L}$ at $37^{\circ} \mathrm{C}$. Finally, using FL2 (585/42 nm)-FL1 (530/30 nm) channels, the red-green fluorescence intensity of $1 \times 10^{4}$ events was acquired immediately on FACSCalibur flow cytometer. Data were analyzed using CellQuest ${ }^{\mathrm{TM}}$ software (Becton Dickinson) gating out debris. Bar graphs were created by GraphPad Prism ${ }^{\circledR} 5$.

\subsection{Confocal Laser Scanning Microscopy}

PANC-1 cells $\left(2 \times 10^{5}\right)$ were plated on $\mu$-Slide 8 Well Glass Bottom dishes (Ibidi ${ }^{\circledR}$,Martinsried, Germany) in $500 \mu \mathrm{L}$ media and placed in a humidified incubator at $37^{\circ} \mathrm{C} 5 \% \mathrm{CO}_{2}$. After $24 \mathrm{~h}$ culturing, detection of curcumin, curcumin analogs $(1 \mu \mathrm{M}, 5 \mathrm{~min})$ and ER tracker green $(1 \mu \mathrm{M}$, 5 min, Thermo Fisher) were performed using Olympus Fluoview FV1000 confocal laser scanning microscope (Olympus Life Science Europa GmbH, Hamburg, Germany ) in triplicates. Microscope configuration was the following: objective: UPLFLN 40× (oil, NA:1.3); dichroic mirror: 20/80, excitation: $405 \mathrm{~nm}$ (curcumin analogs), $514 \mathrm{~nm}$ (ER tracker); detection range: $425-475 \mathrm{~nm}$ (curcumin), 530-630 nm (ER tracker); scanning dimensions: $512 \times 512$ pixel; sampling speed: $2 \mu$ s/pixel; confocal aperture: $182 \mu \mathrm{m}$; zoom: $5 \times$; line averaging: $2 \times$. Curcumin analogs and ER tracker green images were pseudocolored as cyan and green, respectively. Transmitted light images were also captured with $514 \mathrm{~nm}$ laser and paired with each fluorescence image. ER tracker green imaging was performed using 
$514 \mathrm{~nm}$ laser instead of $488 \mathrm{~nm}$ laser to minimize channel crosstalk. Composite images were prepared using CorelDraw ${ }^{\circledR}$ Graphics Suite X7 (Corel, Ottawa, Canada).

\subsection{Gene Expression Analysis}

PANC-1 cells $\left(2 \times 10^{6}\right)$ were plated in $60 \mathrm{~mm}$ tissue culture dishes (Corning Life Sciences) in RPMI 10\% FCS. Twenty-four hours later cells were treated in $5 \mathrm{~mL}$ volume with test compounds. After $12 \mathrm{~h}$ treatment, nucleic acid preparation was done by using the Bioneer RNA purification kit (Bioneer, Viral RNA extraction kit, Daejeon, South Korea) according to an already published protocol [37] with modifications [38]. The quality and quantity of the isolated RNA were measured with NanoDrop1000 Version 3.8.1. (Thermo Fisher Scientific).

Reverse transcription from $3 \mu \mathrm{g}$ of total RNA was performed with the High-Capacity cDNA Archive Kit (Applied Biosystems, Foster City, California, USA) in a total volume of $30 \mu \mathrm{L}$ according to the manufacturer's protocol. After dilution with $130 \mu \mathrm{L}$ of ultrapure water (Applied Biosystems) cDNA was used as template for gene expression analysis. Quantitative real-time PCR (qRT-PCR) was performed on the LightCycler®Nano Instrument (Roche, Basel, Switzerland) using gene-specific primers with SYBR Green protocol as described previously [38]. Briefly: for cycling each $10 \mu \mathrm{L}$ PCR reaction contained $1 \mu \mathrm{L}$ cDNA, $250 \mathrm{nM}$ primers and $5 \mu \mathrm{L}$ FastStart Essential DNA Green Master $(2 \times$, Roche). Primers were as follows:

Heat Shock Protein Family A (Hsp70) Member 5 (HSPA5, NM_005347.4), HSPA5-F 5'-AGCCTGGCGACAAGAGTG-3', HSPA5-R 5'- TCCTTGGGCAGTATTGGATT-3'; the following primer sequences are referenced by [17]: Activating Transcription Factor 4 (ATF4, NM_182810.2, NM_001675.4), X-Box Binding Protein 1 (XBP1, NM_005080.3, NM_001079539.1), DNA Damage Inducible Transcript 3 (DDIT3, NM_004083.5, M_001195056.1, NM_001195055.1, NM_001195054.1, NM_001195053.1), $\beta$-actin (ACTB, BC002409.2).

The PCR protocol was as follows: enzyme activation at $95^{\circ} \mathrm{C}$ for $10 \mathrm{~min}, 45$ cycles of denaturation at $95{ }^{\circ} \mathrm{C}$ for $15 \mathrm{~s}$, annealing at $60^{\circ} \mathrm{C}$ and extension at $72{ }^{\circ} \mathrm{C}$ for $25 \mathrm{~s}$. All the PCRs were performed with three replicates. After amplification, melting curve was checked to verify the specificity of the PCR reactions. The presented relative gene expression ratios were normalized to ACTB gene, calculated

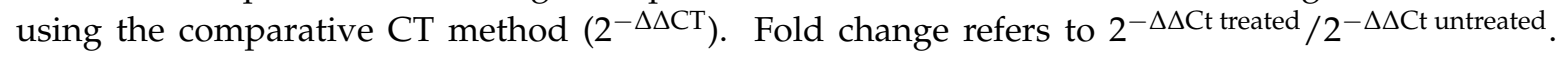
All values are presented as mean \pm standard deviation (SD).

\subsection{Statistical Analysis}

Statistical analysis was performed using two-tailed, homoscedastic Student's t-test to evaluate the statistical significance (set at ${ }^{*} p<0.05,{ }^{* *} p<0.01,{ }^{* * *} p<0.001$ ) using pairwise comparison of each sample to the untreated control in Microsoft ${ }^{\circledR}$ Excel $^{\mathrm{TM}}$.

\section{Conclusions}

Despite the emerging field of targeted anti-cancer therapeutics the combination of different therapeutic strategies (surgery, radiation, chemotherapeutic agents, biologics and immunotherapy etc.) may combat cancer and mount an effective therapeutic response [39-42], however, there is a high need for novel anti-cancer agents with improved cancer cell killing with less side effects.

We designed and synthetized a library of twenty-three achiral curcumin analogs to follow up on our previous work to identify potent, cytotoxic Mannich-base curcuminoids [15,17]. These compounds lack a chiral center so their biological/pharmacological testing is more straightforward without the need for the evaluation of the individual enantiomers. We tested the anti-proliferative activity of our curcumin analogs on human non-small-cell lung carcinoma (A549), hepatocellular carcinoma (HepG2), and pancreatic cancer (PANC-1) cell lines.

Three curcuminoids, C509, C521, and C524 with the highest apoptotic activity were selected for mechanistic studies in the most sensitive PANC-1 cells. We found that the biological activity of the analogs on one hand relied on a cytostatic effect since curcumin and curcuminoid analog 
treatment led to $G_{0} / G_{1}$ cell cycle arrest. On the other hand, our compounds also possessed a potent cytotoxic effect (Figure 9). Their accumulation in the ER caused ER stress, the induction of the unfolded protein response, mitochondrial membrane depolarization, caspase- 3 activation, and subsequently DNA breakdown.

Three curcumin analogs, C509, C521, and C524 possessed superior, 40-times more potent cytotoxic activity compared to the natural dihydroxy-dimetoxycurcumin in human pancreatic cancer cells, offering the possibility for their further investigation.

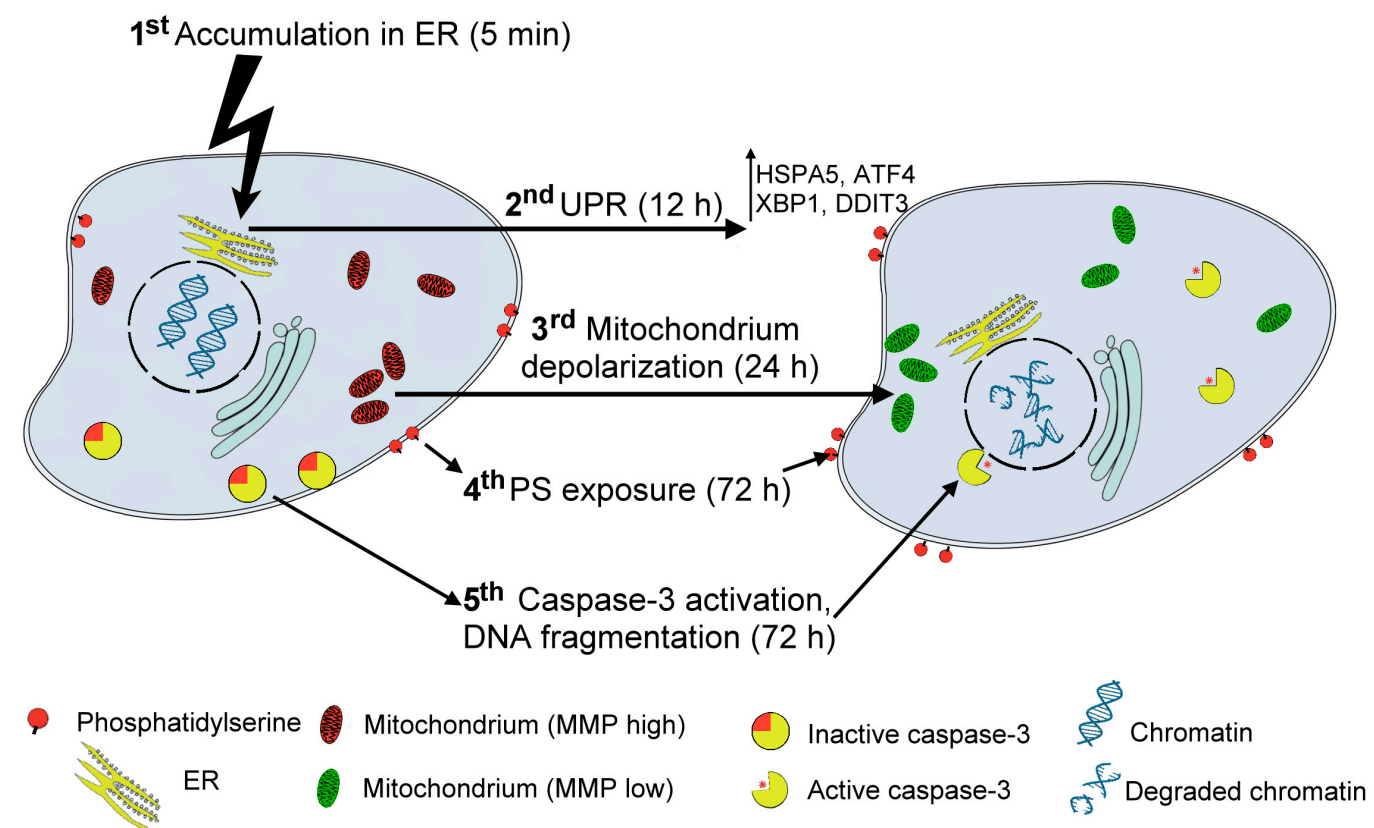

Figure 9. Curcumin and achiral curcumin analogs induce ER stress (1st step) mediated mitochondrial apoptosis in pancreatic PANC-1 cells. The activated unfolded protein response (UPR, 2nd step) induce mitochondrial membrane depolarization (3rd step), PS exposure (4th step) caspase-3 activation and subsequently DNA breakdown (5th step) of pancreatic cancer cells.

Supplementary Materials: Supplementary materials can be found at www.mdpi.com/1422-0067/18/10/2105/s1.

Acknowledgments: We acknowledge Bea Militár Mandákné and Imola Nokta-Mán for excellent tissue culturing, Edit Kotogány for assistance using the flow cytometer. This work was supported by the following grants: GINOP-2.3.2-15-2016-00030 for László G. Puskás and GINOP-2.3.2-15-2016-00001 for László G. Puskas, Ferhan Ayaydin and Roberta Fajka-Boja from the National Research, Development and Innovation Office (NKFI), Hungary. Gábor J. Szebeni was supported by János Bolyai Research Scholarship of the Hungarian Academy of Sciences $(\mathrm{BO} / 00139 / 17 / 8)$.

Author Contributions: Gábor J. Szebeni, Árpád Balázs, Iván Kanizsai, László Hackler Jr. and László G. Puskás conceived and designed the experiments. Gábor J. Szebeni, Árpád Balázs, Ildikó Madarász, Gábor Pócz, Ferhan Ayaydin, Roberta Fajka-Boja, and Róbert Alföldi performed the experiments. Gábor J. Szebeni, László Hackler Jr. and László G. Puskás analyzed the data. Gábor J. Szebeni, Árpád Balázs, László Hackler, Jr. and László G. Puskás wrote the paper.

Conflicts of Interest: The authors declare no conflict of interest. 


\section{Abbreviations}

$\begin{array}{ll}\text { AnnV } & \text { Annexin V-Alexa Fluor }{ }^{\circledR 88} \\ \text { CDKN2A } & \text { Cyclin-dependent kinase inhibitor 2A } \\ \text { CDK4 } & \text { Cyclin-dependent kinase } 4 \\ \text { CDK6 } & \text { Cyclin-dependent kinase 6 } \\ \text { Curc } & \text { Curcumin } \\ \text { ER } & \text { Endoplasmic reticulum } \\ \text { GLUT1 } & \text { Glucose transporter-1 } \\ \text { GRAS } & \text { Generally Recognized as Safe } \\ \text { HCC } & \text { Hepatocellular carcinoma } \\ \text { HEPES } & \text { 4-(2-hydroxyethyl)-1-piperazineethanesulfonic acid } \\ \text { IC50 } & \text { Half maximal inhibitory concentration } \\ \text { JC-1 } & \text { 5, } 5^{\prime}, 6,6^{\prime} \text {-tetrachloro-1,1',3,3'-tetraethylbenzimidazolocarbocyanine iodide } \\ \text { NSCLC } & \text { Non-small cell lung cancer } \\ \text { MAPK } & \text { Mitogen-activated protein kinase } \\ \text { MFI } & \text { Median fluorescence intensity } \\ \text { MMP } & \text { Mitochondrial membrane potential } \\ \text { PBS } & \text { Phosphate buffered saline } \\ \text { PI } & \text { Propidium iodide } \\ \text { SAR } & \text { structure-activity relationship } \\ \text { SD } & \text { Standard deviation } \\ \text { UPR } & \text { Unfolded protein response }\end{array}$

\section{References}

1. Gupta, S.C.; Sung, B.; Kim, J.H.; Prasad, S.; Li, S.; Aggarwal, B.B. Multitargeting by turmeric, the golden spice: From kitchen to clinic. Mol. Nutr. Food Res. 2013, 57, 1510-1528. [CrossRef] [PubMed]

2. Kocaadam, B.; Sanlier, N. Curcumin, an active component of turmeric (Curcuma longa), and its effects on health. Crit. Rev. Food Sci. Nutr. 2017, 57, 2889-2895. [CrossRef] [PubMed]

3. Chen, J.; He, Z.M.; Wang, F.L.; Zhang, Z.S.; Liu, X.Z.; Zhai, D.D.; Chen, W.D. Curcumin and its promise as an anticancer drug: An analysis of its anticancer and antifungal effects in cancer and associated complications from invasive fungal infections. Eur. J. Pharmacol. 2016, 772, 33-42. [CrossRef] [PubMed]

4. Ravindran, J.; Prasad, S.; Aggarwal, B.B. Curcumin and cancer cells: How many ways can curry kill tumor cells selectively? AAPS J. 2009, 11, 495-510. [CrossRef] [PubMed]

5. Perrone, D.; Ardito, F.; Giannatempo, G.; Dioguardi, M.; Troiano, G.; Lo Russo, L.; de Lillo, A.; Laino, L.; Lo Muzio, L. Biological and therapeutic activities, and anticancer properties of curcumin. Exp. Ther. Med. 2015, 10, 1615-1623. [CrossRef] [PubMed]

6. Jin, H.; Qiao, F.; Wang, Y.; Xu, Y.; Shang, Y. Curcumin inhibits cell proliferation and induces apoptosis of human non-small cell lung cancer cells through the upregulation of mir-192-5p and suppression of PI3K/Akt signaling pathway. Oncol. Rep. 2015, 34, 2782-2789. [CrossRef] [PubMed]

7. Yao, Q.; Lin, M.; Wang, Y.; Lai, Y.; Hu, J.; Fu, T.; Wang, L.; Lin, S.; Chen, L.; Guo, Y. Curcumin induces the apoptosis of a549 cells via oxidative stress and MAPK signaling pathways. Int. J. Mol. Med. 2015, 36, 1118-1126. [CrossRef] [PubMed]

8. Tsai, J.R.; Liu, P.L.; Chen, Y.H.; Chou, S.H.; Cheng, Y.J.; Hwang, J.J.; Chong, I.W. Curcumin inhibits non-small cell lung cancer cells metastasis through the adiponectin/nf-kappab/mmps signaling pathway. PLoS ONE 2015, 10, e0144462. [CrossRef] [PubMed]

9. Liao, H.; Wang, Z.; Deng, Z.; Ren, H.; Li, X. Curcumin inhibits lung cancer invasion and metastasis by attenuating glut1/mt1-mmp/mmp2 pathway. Int. J. Clin. Exp. Med. 2015, 8, 8948-8957. [PubMed]

10. Wang, M.; Ruan, Y.; Chen, Q.; Li, S.; Wang, Q.; Cai, J. Curcumin induced hepg2 cell apoptosis-associated mitochondrial membrane potential and intracellular free ca(2+) concentration. Eur. J. Pharmacol. 2011, 650, 41-47. [CrossRef] [PubMed]

11. Fan, H.; Tian, W.; Ma, X. Curcumin induces apoptosis of hepg2 cells via inhibiting fatty acid synthase. Target. Oncol. 2014, 9, 279-286. [CrossRef] [PubMed] 
12. Ramos, M.C.; Boulaiz, H.; Grinan-Lison, C.; Marchal, J.A.; Vicente, F. What's new in treatment of pancreatic cancer: A patent review (2010-2017). Expert Opin. Ther. Pat. 2017. [CrossRef] [PubMed]

13. Diaz Osterman, C.J.; Gonda, A.; Stiff, T.; Sigaran, U.; Valenzuela, M.M.; Ferguson Bennit, H.R.; Moyron, R.B.; Khan, S.; Wall, N.R. Curcumin induces pancreatic adenocarcinoma cell death via reduction of the inhibitors of apoptosis. Pancreas 2016, 45, 101-109. [CrossRef] [PubMed]

14. Zhao, Z.; Li, C.; Xi, H.; Gao, Y.; Xu, D. Curcumin induces apoptosis in pancreatic cancer cells through the induction of forkhead box 01 and inhibition of the PI3K/Akt pathway. Mol. Med. Rep. 2015, 12, 5415-5422. [CrossRef] [PubMed]

15. Nagy, L.I.; Feher, L.Z.; Szebeni, G.J.; Gyuris, M.; Sipos, P.; Alfoldi, R.; Ozsvari, B.; Hackler, L., Jr.; Balazs, A.; Batar, P.; et al. Curcumin and its analogue induce apoptosis in leukemia cells and have additive effects with bortezomib in cellular and xenograft models. Biomed. Res. Int. 2015. [CrossRef] [PubMed]

16. Hackler, L., Jr.; Ozsvari, B.; Gyuris, M.; Sipos, P.; Fabian, G.; Molnar, E.; Marton, A.; Farago, N.; Mihaly, J.; Nagy, L.I.; et al. The curcumin analog C-150, influencing NF-kB, UPR and Akt/Notch pathways has potent anticancer activity in vitro and in vivo. PLoS ONE 2016, 11, e0149832. [CrossRef] [PubMed]

17. Gyuris, M.; Hackler, L., Jr.; Nagy, L.I.; Alfoldi, R.; Redei, E.; Marton, A.; Vellai, T.; Farago, N.; Ozsvari, B.; Hetenyi, A.; et al. Mannich curcuminoids as potent anticancer agents. Arch. Pharm. 2017, 350, e1700005. [CrossRef] [PubMed]

18. Gyuris, M.; Puskas, L.G.; Kanizsai, I.; Ozsvari, B.; Hackler, L.; Nagy, L.I. Novel Medicinal Compounds-Preparation of Curcumin Derivatives for Treatment of Cancer and Inflammation. International Patent Application No. PCT WO2013041895 A1, 28 March 2013.

19. Jackson, S.J.; Murphy, L.L.; Venema, R.C.; Singletary, K.W.; Young, A.J. Curcumin binds tubulin, induces mitotic catastrophe, and impedes normal endothelial cell proliferation. Food Chem. Toxicol. 2013, 60, 431-438. [CrossRef] [PubMed]

20. Hu, A.; Huang, J.J.; Zhang, J.F.; Dai, W.J.; Li, R.L.; Lu, Z.Y.; Duan, J.L.; Li, J.P.; Chen, X.P.; Fan, J.P.; et al. Curcumin induces G2/M cell cycle arrest and apoptosis of head and neck squamous cell carcinoma in vitro and in vivo through ATM/Chk2/p53-dependent pathway. Oncotarget 2017, 8, 50747-50760. [CrossRef] [PubMed]

21. Srivastava, R.K.; Chen, Q.; Siddiqui, I.; Sarva, K.; Shankar, S. Linkage of curcumin-induced cell cycle arrest and apoptosis by cyclin-dependent kinase inhibitor p21(/waf1/cip1). Cell Cycle 2007, 6, 2953-2961. [CrossRef] [PubMed]

22. Sha, J.; Li, J.; Wang, W.; Pan, L.; Cheng, J.; Li, L.; Zhao, H.; Lin, W. Curcumin induces g0/g1 arrest and apoptosis in hormone independent prostate cancer du-145 cells by down regulating notch signaling. Biomed. Pharmacother. 2016, 84, 177-184. [CrossRef] [PubMed]

23. Nagy, L.I.; Molnar, E.; Kanizsai, I.; Madacsi, R.; Ozsvari, B.; Feher, L.Z.; Fabian, G.; Marton, A.; Vizler, C.; Ayaydin, F.; et al. Lipid droplet binding thalidomide analogs activate endoplasmic reticulum stress and suppress hepatocellular carcinoma in a chemically induced transgenic mouse model. Lipids Health Dis. 2013, 12, 175. [CrossRef] [PubMed]

24. Kim, B.; Kim, H.S.; Jung, E.J.; Lee, J.Y.; Tsang, B.K.; Lim, J.M.; Song, Y.S. Curcumin induces ER stress-mediated apoptosis through selective generation of reactive oxygen species in cervical cancer cells. Mol. Carcinog. 2016, 55, 918-928. [CrossRef] [PubMed]

25. Chignell, C.F.; Bilski, P.; Reszka, K.J.; Motten, A.G.; Sik, R.H.; Dahl, T.A. Spectral and photochemical properties of curcumin. Photochem. Photobiol. 1994, 59, 295-302. [CrossRef] [PubMed]

26. Gessner, D.K.; Schlegel, G.; Ringseis, R.; Schwarz, F.J; Eder, K. Up-regulation of endoplasmic reticulum stress induced genes of the unfolded protein response in the liver of periparturient dairy cows. BMC Vet. Res. 2014, 10, 46. [CrossRef] [PubMed]

27. Cerezo, M.; Rocchi, S. New anti-cancer molecules targeting HSPA5/BIP to induce endoplasmic reticulum stress, autophagy and apoptosis. Autophagy 2017, 13, 216-217. [CrossRef] [PubMed]

28. Cnop, M.; Foufelle, F.; Velloso, L.A. Endoplasmic reticulum stress, obesity and diabetes. Trends Mol. Med. 2012, 18, 59-68. [CrossRef] [PubMed]

29. Li, Y.; Guo, Y.; Tang, J.; Jiang, J.; Chen, Z. New insights into the roles of chop-induced apoptosis in ER stress. Acta Biochim. Biophys. Sin. 2014, 46, 629-640. [CrossRef] [PubMed]

30. Sano, R.; Reed, J.C. Er stress-induced cell death mechanisms. Biochim. Biophys. Acta 2013, 1833, 3460-3470. [CrossRef] [PubMed] 
31. Gupta, S.; Cuffe, L.; Szegezdi, E.; Logue, S.E.; Neary, C.; Healy, S.; Samali, A. Mechanisms of ER stress-mediated mitochondrial membrane permeabilization. Int. J. Cell Biol. 2010, 2010, 170215. [CrossRef] [PubMed]

32. Henry-Mowatt, J.; Dive, C.; Martinou, J.C.; James, D. Role of mitochondrial membrane permeabilization in apoptosis and cancer. Oncogene 2004, 23, 2850-2860. [CrossRef] [PubMed]

33. Kajstura, M.; Halicka, H.D.; Pryjma, J.; Darzynkiewicz, Z. Discontinuous fragmentation of nuclear DNA during apoptosis revealed by discrete "sub-g1" peaks on DNA content histograms. Cytometry A 2007, 71, 125-131. [CrossRef] [PubMed]

34. Riss, T.L.; Moravec, R.A.; Niles, A.L.; Duellman, S.; Benink, H.A.; Worzella, T.J.; Minor, L. Cell Viability Assays; Eli Lilly \& Company and the National Center for Advancing Translational Sciences: Bethesda, MD, USA, 2004. Available online: http:/ / www.ncbi.nlm.nih.gov/pubmed/23805433 (accessed on 26 September 2017).

35. Fajka-Boja, R.; Hidvegi, M.; Shoenfeld, Y.; Ion, G.; Demydenko, D.; Tomoskozi-Farkas, R.; Vizler, C.; Telekes, A.; Resetar, A.; Monostori, E. Fermented wheat germ extract induces apoptosis and downregulation of major histocompatibility complex class I proteins in tumor T and B cell lines. Int. J. Oncol. 2002, 20, 563-570. [CrossRef] [PubMed]

36. Sharrow, S.O. Analysis of flow cytometry data. Curr. Protoc. Immunol. 1996. [CrossRef]

37. Puskas, L.G.; Feher, L.Z.; Vizler, C.; Ayaydin, F.; Raso, E.; Molnar, E.; Magyary, I.; Kanizsai, I.; Gyuris, M.; Madacsi, R.; et al. Polyunsaturated fatty acids synergize with lipid droplet binding thalidomide analogs to induce oxidative stress in cancer cells. Lipids Health Dis. 2010, 9, 56. [CrossRef] [PubMed]

38. Szebeni, G.J.; Tancos, Z.; Feher, L.Z.; Alfoldi, R.; Kobolak, J.; Dinnyes, A.; Puskas, L.G. Real architecture for $3 \mathrm{D}$ tissue (raft) culture system improves viability and maintains insulin and glucagon production of mouse pancreatic islet cells. Cytotechnology 2017, 69, 359-369. [CrossRef] [PubMed]

39. Hughes, P.E.; Caenepeel, S.; Wu, L.C. Targeted therapy and checkpoint immunotherapy combinations for the treatment of cancer. Trends Immunol. 2016, 37, 462-476. [CrossRef] [PubMed]

40. Thomas, A.; Teicher, B.A.; Hassan, R. Antibody-drug conjugates for cancer therapy. Lancet Oncol. 2016, 17, e254-e262. [CrossRef]

41. Al-Lazikani, B.; Banerji, U.; Workman, P. Combinatorial drug therapy for cancer in the post-genomic era. Nat. Biotechnol. 2012, 30, 679-692. [CrossRef] [PubMed]

42. Szebeni, G.J.; Vizler, C.; Nagy, L.I.; Kitajka, K.; Puskas, L.G. Pro-tumoral inflammatory myeloid cells as emerging therapeutic targets. Int. J. Mol. Sci. 2016, 17, 1958. [CrossRef] [PubMed] 